To be published as: Moreno-Lax, 'Mutual (Dis-)Trust in EU Migration and Asylum Law: The Exceptionalisation of Fundamental Rights', in González Pascual and Iglesias Sánchez (eds), Fundamental Rights in the EU Area of Freedom, Security and Justice (CUP, 2020).

\title{
Mutual (Dis-)Trust in EU Migration and Asylum Law: The Exceptionalisation of Fundamental Rights
}

\author{
Violeta Moreno-Lax*
}

\begin{abstract}
This chapter deals with the functioning of 'mutual trust' as the organising principle of mechanisms of (implicit) mutual recognition in the fields of migration and asylum within the AFSJ, looking both at rights-conferring and rights-restricting measures, comparing their treatment. The chapter uncovers a contradictory dynamic whereby the mutual recognition of rights-restricting measures across the EU is near-automatic and practically unconditional, while the mutual recognition of rights-conferring measures virtually non-existent. The reason for this is claimed to be the interplay between presumed (abstract) trust, as required by the case law of the CJEU, and the real (practical) distrust, professed at horizontal and vertical level in the day-to-day administration of EU migration and asylum governance. Such interplay produces insidious effects on third-country nationals, particularly in the case of asylum applicants, leading to the arbitrary 'exceptionalisation' of their fundamental rights.
\end{abstract}

KEYWORDS: Mutual trust, 'collectivised' mutual recognition, horizontal and vertical dis-trust, migration, asylum, rights-conferring measures, rights-restricting measures, SIS alert, entry ban, expulsion order, Dublin transfer, rule of reason, exequatur, exceptionalisation of fundamental rights

\section{Introduction: The Objectivation of Mutual (Dis-)Trust}

'Mutual trust' (or 'mutual confidence') has been relied upon as the organising principle of mechanisms of (implicit) mutual recognition in the fields of migration and asylum law within the AFSJ-where intra-EU frontiers demarcate the borders of rights and responsibility for third-country nationals (TCNs). Its use is most prominent in relation to coercive measures, particularly forcible transfers between Member States (MSs) of asylum seekers under the Dublin Regulation. ${ }^{1}$ But it plays also a (tacit) role, e.g., in the removal of irregular migrants under the Return Directive framework. ${ }^{2}$ Correspondingly, that trust constitutes the basis for mutual recognition of rejection decisions of asylum claims and of expulsion orders in the organisation of return operations. As a result, 'mutual trust' has been said to be 'of fundamental importance in EU law', 3 and treated as grounded in the founding values of the Union and as having constitutional significance. ${ }^{4}$

Like in other areas, its basis is the presumption of compliance by MSs with their EU law obligations, including fundamental rights, which the CJEU considers

\footnotetext{
* Reader in Law, Queen Mary University of London. This chapter is a deliverable of the MAPS

${ }^{1}$ Dublin III Regulation, [2013] OJ L180/31 ('DRIII').

${ }^{2}$ Return Directive, [2008] OJ L 348/98.

${ }^{3}$ Opinion 2/13 ECLI:EU:C:2014:2454, para. 191. Cf. Moreno-Lax, 'The Axiological Emancipation of a (Non-)Principle: Autonomy, International Law and the EU Legal Order', in Govaere and Garben (eds), The Interface Between EU and International Law (Hart, 2019) 45.

${ }^{4}$ See, extensively, Janssens, The Principle of Mutual Recognition in EU Law (OUP, 2013); and Xanthopoulou, Fundamental Rights and Mutual Trust in the AFSJ (Hart, 2020).
} 
To be published as: Moreno-Lax, 'Mutual (Dis-)Trust in EU Migration and Asylum Law: The Exceptionalisation of Fundamental Rights', in González Pascual and Iglesias Sánchez (eds), Fundamental Rights in the EU Area of Freedom, Security and Justice (CUP, 2020).

rebuttable, however, only in extreme cases. ${ }^{5}$ Particularly after Opinion 2/13, the 'exceptionalisation' of fundamental rights has translated into an 'obligation to presume' such compliance, so that, 'save in exceptional cases', a MS cannot check whether another MS has 'actually, in a specific case', observed its fundamental rights obligations. ${ }^{6}$ Yet, presumptions in law normally work as procedural devices to apportion the burden of proof, on grounds of procedural economy, where there are (good) reasons for the generalisation of 'foundedness' or 'ill-foundedness' of claims. Making of presumptions (quasi-)absolute rules, assigning them substantive value of their own, independently from any real basis on which they may be grounded, can lead to absurd (and arbitrary) outcomes. With this in mind, this chapter will track the implications of such 'objectivation' of mutual trust in EU migration and asylum law to assess its compatibility with the 'founding values', especially 'respect for human rights', enshrined in Article 2 TEU, particularly within the Dublin system.

The focus on mutual trust is justified by the fact that, unlike cooperation in civil and criminal matters, ${ }^{7}$ integration in the area of migration and asylum policy has not been explicitly founded on a system of mutual recognition. There is no equivalent provision in the Lisbon Treaty to Articles 81 and 82 TFEU regarding cooperation in this field. ${ }^{8}$ However, this does not mean that mechanisms similar, in their working and effects, to mutual recognition have not emerged, as the next sections will demonstrate. There is, nevertheless, an important element that sets cooperation in immigration and asylum matters apart. There is, in this area, a dual, if not contradictory, dynamic at play, whereby the recognition of restrictive measures across the EU is seamless, near-automatic and practically unconditional, while the recognition of favourable measures, giving extraterritorial validity to 'positive' decisions and extending TCN rights across jurisdictions, is virtually non-existent.

This contradictory dynamic — it is posited — is the result of the co-existence of two different forms of real (rather than presumed) dis-trust: vertical and horizontal. Vertical distrust refers to the lack of confidence in TCNs and their perception as potential abusers of the EU mobility regime, with that abuse, in turn, considered as posing an existential threat to the AFSJ. Horizontal distrust, by contrast, captures the lack of confidence at inter-state level between EU MSs inter se that seems to pervade migration and asylum decisions. These two types of practical distrust reinforce one another with very tangible repercussions in the way TCN rights are restricted, rather than expanded, in the cross-EU operation of migration and asylum measures.

The interplay of presumed (abstract) trust, as required by the case law of the CJEU, and the real (practical) distrust, professed at horizontal and vertical level in the day-to-day administration of migration and asylum governance in the EU, is what the following sections will unpack. Section 2 will look at mutual recognition/mutual trust

\footnotetext{
${ }^{5}$ For the first time the presumption was considered rebuttable, see Joined Cases C-411/10 and C493/10 N.S. and M.E. [2011] ECR I-13905.

${ }^{6}$ Opinion 2/13 (n 3), para. 192.

${ }^{7}$ For a detailed account, see Millet and Mitsilegas in this volume.

${ }^{8}$ See also Art. 67(3)-(4) TFEU.
} 
To be published as: Moreno-Lax, 'Mutual (Dis-)Trust in EU Migration and Asylum Law: The Exceptionalisation of Fundamental Rights', in González Pascual and Iglesias Sánchez (eds), Fundamental Rights in the EU Area of Freedom, Security and Justice (CUP, 2020).

in the migration field, while Section 3 will turn to mutual recognition/mutual trust in refugee protection. One common conclusion will be reached, in Section 4, regarding the insidious effects of this interplay on the fundamental rights of TCNs, with a collateral (yet essential) impact on the supremacy and uniform application of EU law.

\section{Mutual Recognition and EU Migration Law}

In line with the dialectic underpinning horizontal/vertical, abstract/practical, trust/distrust, the next sections show how the Directives conferring mobility rights to certain categories of economically-active TCNs embrace an embryonic system of bestowment of (very limited) trans-national effects to the administrative (immigration) decisions adopted by the MS of 'first admission' according rights to TCNs. By contrast, the EU-wide validity of administrative (immigration) decisions limiting rights, whether in the form of expulsion orders or re-entry bans, is virtually automatic and un-contestable at the inter-State level.

\subsection{Mutual Recognition of Rights-conferring Measures}

Economically active TCNs have been excluded from free movement rights. ${ }^{9}$ They can be granted certain possibilities to move between MSs pursuant to Schengen rules and the legal immigration Directives, but their situation is qualitatively very different from that of economically-active EU citizens - the grounds for their exclusion, however, not being based on sound economic, market integration reasoning. ${ }^{10}$ While the Schengen Convention (CISA) grants short-term travel rights, ${ }^{11}$ the legal immigration Directives contemplate options for longer-time mobility across the EU.

Under Article 21 CISA, 'aliens who hold valid residence permits issued by one of the Contracting Parties may, on the basis of that permit and a valid travel document, move freely for up to three months [within the Schengen area]'. Implicitly, this entails the recognition by all Schengen countries of the validity of residence permits issued by any one of them. There is no specific procedure established to this effect. The second MS may, nonetheless, reject access to its territory if it deems that the TCN does not fulfil the entry conditions established in Schengen rules or if she appears 'on the national list of [security] alerts of the Contracting Party concerned'. 12 So, the mutual recognition exercise is not based on immediate and unconditional trust in the residence permit decisions of all Schengen partners, and the related extension of rights depends not only on the decision by the State issuing the permit, but also on the (subsequent and independent) decision on admission by the State the person may

\footnotetext{
${ }^{9}$ See further Iglesias Sánchez, 'Free Movement of Third-country Nationals in the European Union? Main Features, Deficiencies and Challenges of the new Mobility Rights in the Area of Freedom, Security and Justice' (2009) 15 ELJ 791.

${ }^{10} \mathrm{Cf}$. Wiesbrock, 'Free Movement of Third-Country Nationals in the European Union: The Illusion of Inclusion' (2012) 35 ELRev 455.

${ }^{11}$ Convention implementing the Schengen Agreement, [2000] OJ L 239/19 ('CISA').

${ }^{12}$ Art. 21(1) CISA.
} 
To be published as: Moreno-Lax, 'Mutual (Dis-)Trust in EU Migration and Asylum Law: The Exceptionalisation of Fundamental Rights', in González Pascual and Iglesias Sánchez (eds), Fundamental Rights in the EU Area of Freedom, Security and Justice (CUP, 2020).

seek to access. These are two separate sovereign decisions adopted by two different MSs - rather than only one that the first MS issues and the second MS recognises and implements, as it happens under the EAW system and other (explicit and more) advanced mutual recognition regimes within the AFSJ. ${ }^{13}$

Beside short-term travel rights, certain categories of TCNs may also be entitled to longer-term mobility within the EU. This is the case under both (some of) the 'first admission' Directives, ${ }^{14}$ regulating the entry into the Union of students, researchers, ${ }^{15}$ highly-qualified workers, ${ }^{16}$ and intra-corporate transferees, ${ }^{17}$ as well as the Long-term Residence (LTR) Directive, ${ }^{18}$ governing the conditions for settlement in a different MS of established (and presumably 'well integrated') TCNs. Yet, also in this case, the system is not entirely based on the mutual recognition of national decisions.

Researchers, for instance, may be granted short-term as well as long-term mobility rights, if in possession of an authorisation issued by a 'first' MS to carry out part of their activity in one or several other 'second' MSs, respectively for a period of up to, or longer than, six months in any one-year period per MS. ${ }^{19}$ The exercise of these rights is subject to a process of notification to, and possible objection by, the second MS(s), which closely resembles the process of initial authorisation by the first MS foreseen in the Directive. So, just like the first MS may refuse entry on grounds, e.g., that the researcher is not in possession of appropriate sickness insurance or lacks sufficient resources to cover subsistence costs, the second MS(s) may undertake their own evaluation at the point of mobility and reject access to their territory on the same basis. $^{20}$

From their part, student mobility rights are subject to a very similar process. They, too, can transfer their residence from one to another MS by complying with requirements for access to a second $\mathrm{MS}$, which essentially replicate the conditions for entry in the first MS. ${ }^{21}$ And the same applies to Blue Card holders, whose treatment, though more favourable in substantive terms, ${ }^{22}$ follows a comparable procedure. After 18 months of legal residence in a first MS, they are entitled to move to a second MS for highly-qualified employment, but remain subject to a (separate) process of application (and possible rejection) for a (new) Blue Card to that second MS, which

\footnotetext{
${ }^{13}$ See, e.g., Mitsilegas, 'The Constitutional Implications of Mutual Recognition in Criminal Matters in the EU' (2006) 43 CMLRev 1277; and van Ballegooij, The Nature of Mutual Recognition in European Law (Intersentia, 2015).

${ }^{14}$ This excludes seasonal workers under Directive 2014/36/EU and 'single permit' holders under Directive 2011/98/EU, who are typically perceived as low- or semi-skilled labour and the facilitation of their movement understood more as a security risk than an economic asset.

${ }^{15}$ The regime governing students and researchers has, since 2016, been unified in Directive 2016/801, [2016] OJ L 132/21 ('Students/Researchers Directive').

${ }^{16}$ Blue Card Directive 2009/50/EC, [2009] OJ L 155/1.

${ }^{17}$ Intra-corporate Transferees Directive 2014/66/EU, [2014] OJ L157/1 ('ICT Directive').

${ }^{18}$ Long-term Residence Directive 2003/109/EC, [2004] OJ L 16/44 ('LTR Directive').

${ }^{19}$ Arts 28(1) and 29(1), Students/Researchers Directive.

${ }^{20}$ Art. 28(3)-(9) and Art. 29(2)-(7), Students/Researchers Directive.

${ }^{21}$ Art. 31, Students/Researchers Directive.

${ }^{22}$ See, e.g., Arts 14-16, Blue Card Directive, on equal treatment, family rights, and access to LTR.
} 
To be published as: Moreno-Lax, 'Mutual (Dis-)Trust in EU Migration and Asylum Law: The Exceptionalisation of Fundamental Rights', in González Pascual and Iglesias Sánchez (eds), Fundamental Rights in the EU Area of Freedom, Security and Justice (CUP, 2020).

will check whether the conditions for issuing it—which are the same that the first MS had to check to decide on the issuing of the initial Blue Card-have been complied with. $^{23}$

Even intra-corporate transferees, who accrue mobility rights instantly upon receipt of their initial permit, need to satisfy the authorities of a second MS that they fulfil the conditions for intra-EU transfers. If moving for a short period of time to work in another entity established in a second MS, but 'belonging to the same undertaking or group of undertakings' - thus without changing employer - the process is subject to an authorisation request to which the second MS may, nonetheless, object. ${ }^{24}$ And, if moving for a longer period of time, the second MS has a choice: either follow the same process as for short-term mobility requests or require a separate 'application for long-term mobility', subject to practically the same conditions applicable to the initial permit granted by the first $\mathrm{MS}^{25}$

The mobility of long-term residents, who have spent more than five years in a first MS and have obtained LTR status under EU law, is also conditioned on a separate application being made to the second MS under the terms of the LTR Directive. ${ }^{26}$ It is only in this case where EU rules prevent the full duplication of application conditions, so that applicants in the second MS cannot, for instance, be subject to the entire range of integration measures, if they were already required to comply with integration conditions in the first $\mathrm{MS}^{27}$ This constitutes an embryonic acknowledgement of a certain 'rule of reason'-similar to that governing the free movement of goods ${ }^{28}$ —avoiding 'double burden' situations to a limited extent, but remains far from a comprehensive recognition of equivalence of MS rules and decisions. ${ }^{29}$ It does not pre-empt ('fresh') checks by the second MS of sufficient resources, sickness insurance, or language proficiency of the TCN concerned. The right to settle in the second MS is also limitable on account of quotas or labour preference tests. ${ }^{30}$ What the LTR Directive does, in the end, is simply harmonise the criteria for issuing LTR permits and establish a mechanism that eases intra-EU mobility for permit holders, so they cannot, for instance, be asked to return to their country of origin to apply from there for permission to settle in a second MS. But there is only very limited recognition of the validity of the rules and decisions of the first MS by the (potential) second MS(s), which maintain a high level of discretion and are not obliged to execute the decisions of the first MS within their jurisdictions.

So, overall, the legal immigration Directives' regime facilitates intra-EU migration to a limited extent, the portability of rights not being automatically accepted

\footnotetext{
${ }^{23}$ Art. 18(2), Blue Card Directive, referring back to Art. 5 on 'criteria for admission'.

${ }^{24}$ Art. 21, ICT Directive.

${ }^{25}$ Art. 22, ICT Directive.

${ }^{26}$ Art. 15, LTR Directive.

${ }^{27}$ Art. 15(3), LTR Directive.

${ }^{28}$ See Cambien, 'Mutual Recognition and Mutual Trust in the Internal Market' (2017) 2 European Papers 93; and, more generally, Amstrong, 'Mutual Recognition', in Barnard and Scott (eds), The Law of the Single European Market (Hart, 2002) 225.

${ }^{29}$ Following the logic of Cassis de Dijon, Case 120/78 Rewe-Zentral ECLI:EU:C:1979:42.

${ }^{30}$ Art. 14(3)-(4), LTR Directive.
} 
To be published as: Moreno-Lax, 'Mutual (Dis-)Trust in EU Migration and Asylum Law: The Exceptionalisation of Fundamental Rights', in González Pascual and Iglesias Sánchez (eds), Fundamental Rights in the EU Area of Freedom, Security and Justice (CUP, 2020).

in the absence of express provision for the mutual recognition of admission and residence decisions. The idea, instead, is that harmonisation 'promotes mutual confidence' between $\mathrm{MSs},{ }^{31}$ in a way that, perhaps in the future, may lead to the establishment of a regime of mutual recognition of admission and residence decisions with validity throughout the EU. But this is not yet the case.

This fragmentation of the mobility regime defies market logics, but there are concrete reasons that buttress the underlying policy choice. The seemingly irrational choice - at least from an economic perspective - can be attributed to the two types of distrust pointed out above. Horizontal distrust is manifested in the legal reservation contained in Article 79 TFEU, according to which the (sovereign) 'right' (at international law) to determine the 'volumes of admission' to their territories of TCNs for employment purposes remains with (each one of) the MSs (separately from the EU and independently from each other) as a matter of primary law. ${ }^{32}$ The reservation has been transposed to secondary law, ${ }^{33}$ and is reflective of the high political sensitivity of migration matters and their perception as an issue affecting the core of national autonomy. This perception is arguably what led, since the early years of EU integration, to the exclusion of TCNs from freedom of movement and their simultaneous 'securitisation' as a potential threat to the Single Market. ${ }^{34}$

Discussions on the need to approximate domestic rules on the treatment of TCNs began in the 70s, within negotiations on the removal of internal frontiers, the emphasis put on control and the perceived security deficit that the transfer of checks to the common external borders would entail. Non-EU nationals became the object of 'compensatory' measures, first introduced by the Schengen instruments, based on the understanding that free movement rights benefit '[EU] nationals' only. ${ }^{35}$ The Treaty of Amsterdam, inserting the notion of an AFSJ 'flanking' the internal market, confirmed the approach, giving the Council unfettered discretion to define 'the rights and conditions under which nationals of third countries...legally resident in a MS [could] reside in other MSs' ${ }^{36}$ Lisbon has inherited this rationale. ${ }^{37}$ And even the Charter distinguishes between EU citizens and migrants in the allocation of free movement rights. While 'every citizen of the Union has the right to move and reside freely within the territory of the MSs', for TCNs 'freedom of movement and residence may be granted' through legislative acts. ${ }^{38}$

This persistent exclusion of TCNs from free movement rights - and the concomitant need to police it - is, thus, what explains the necessity to maintain mechanisms of control, to detect whether/when mobility rights have been correctly applied. However, a system of 'home State' control, similar to the one at play within

\footnotetext{
${ }^{31}$ Preamble, Recital 17, LTR Directive (emphasis added).

${ }^{32}$ Art. 79(5) TFEU.

${ }^{33}$ See Art. 6, Blue Card Directive and Art. 6, Students/Researchers Directive.

${ }^{34}$ See, e.g., Huysmans, 'The EU and the Securitization of Migration' (2000) 38 JCMS 751.

${ }^{35}$ Preamble, Schengen Agreement, [2000] OJ L 239/13.

${ }^{36}$ Art. 63(4) EC, Amsterdam Treaty.

${ }^{37}$ Art. 79(2)(b) TFEU.

${ }^{38}$ Art. 45(1)-(2), Charter of Fundamental Rights, [2010] OJ C 83/389 ('CFR') (emphasis added).
} 
To be published as: Moreno-Lax, 'Mutual (Dis-)Trust in EU Migration and Asylum Law: The Exceptionalisation of Fundamental Rights', in González Pascual and Iglesias Sánchez (eds), Fundamental Rights in the EU Area of Freedom, Security and Justice (CUP, 2020).

the free movement of goods, could have been introduced to avoid multiple regulatory burdens and lengthy procedures in several MSs. Why this has not been the case can only be attributed to the absence of trust, both in the control mechanisms of fellow MSs and in the TCNs themselves.

\subsection{Mutual Recognition of Rights-restricting Measures}

Distrust of TCNs is not only manifested in their exclusion from free movement rights, but also in their representation as a threat to the process of European integration. ${ }^{39}$ Because a border-free market may potentially facilitate the movement not only of law-abiding agents, but also that of criminals and 'illegal immigrants', EU border and migration controls have been reframed into a security question-the uncontrolled movement of TCNs being pictured as as much of a challenge to public order and national security as terrorism, drug trafficking or money laundering. ${ }^{40}$ So, in the construction of an 'area' without internal borders, ${ }^{41}$ controls over the movement of TCNs, far from being abolished, have only been de-localized to the other (juxtaposed) 'area' of FSJ that flanks the Single Market. ${ }^{42}$ Whereas the latter requires the removal of borders for the accomplishment of the free movement of persons that only EU citizens enjoy in full, the former is 'premised upon' the existence of those same borders, ${ }^{43}$ which - after the elimination of intra-EU frontiers-need to be reconverted into alternative mechanisms that secure an equivalent level of control over TCNs. Consequently, the adoption of alternative mechanisms of control over the movement of TCNs, 'at all stages', has become a key priority of EU, especially through 'enhanced measures to combat illegal immigration'. ${ }^{4}$

It is in this context that a mechanism of mutual recognition of expulsion decisions emerged in the Expulsion Decisions Directive (EDD), as the only elaborate example of a structure based (explicitly) on horizontal trust between the MSs in the migration policy field. ${ }^{45}$ The European Pact on Immigration and Asylum provided political momentum, calling for 'an expulsion decision taken by one MS [to be] applicable throughout the European Union'. ${ }^{46}$ The Schengen Information System

\footnotetext{
${ }^{39}$ See, e.g., Donner, 'Comments on the Article by Fernhout', in Winter et al. (eds.), Reforming the Treaty on European Union, (Kluwer, 1996), at 402: 'Re-enforcing the rights of immigrants and criminals will not result in an ever closer Union, but rather in the opposite'.

${ }^{40}$ Arts 7 and 17, Schengen Agreement. See also Preamble to CISA.

${ }^{41}$ Art. 26(2) TFEU.

${ }^{42}$ Art. 3(2) TEU.

${ }^{43}$ Crowley, 'Differential Free Movement and the Sociology of the "Internal Border"', in Guild and Harlow (eds.), Implementing Amsterdam, (Hart, 2001), at 16.

${ }^{44}$ Art 79 TFEU. For the main measures and their assessment against fundamental rights, see MorenoLax, Accessing Asylum in Europe (OUP, 2017).

${ }^{45}$ Expulsion Decisions Directive 2001/40, [2001] OJ L 149/34 ('EDD’).

${ }^{46}$ European Pact on Immigration and Asylum, Council doc. 13440/08, 24 September 2008, p. 8. For contextualisation, see O'Dowd, 'Mutual Recognition in European Immigration Policy: Harmonised Protection or Coordinated Exclusion?', in Goudappel, Oostland \& Raulus (eds.), The Future of Asylum in the European Union (T.M.C. Asser Press, 2010) 73.
} 
To be published as: Moreno-Lax, 'Mutual (Dis-)Trust in EU Migration and Asylum Law: The Exceptionalisation of Fundamental Rights', in González Pascual and Iglesias Sánchez (eds), Fundamental Rights in the EU Area of Freedom, Security and Justice (CUP, 2020).

(SIS) was envisaged as the vehicle of application. ${ }^{47}$ Within that framework, an 'alert' for an expulsion decision entered in the SIS would oblige other MSs to prevent the TCN concerned from entering/re-entering or remaining within EU territory. The idea has further evolved into an integrated regime of 'entry bans', ${ }^{48}$ which are given 'a European dimension', making them valid across the territory of all MSs, and that all MSs must recognise and implement. ${ }^{49}$ The rationale — as in other mutual recognition schemes within the AFSJ-is 'the need to ensure greater effectiveness in enforcing expulsion decisions and better cooperation between MSs'. ${ }^{50}$

The paramount concern with effectiveness and speed is illustrated by a specific duty of cooperation that binds MSs to 'make use of all appropriate means' to execute deportations, including the sharing of all relevant documents and information required 'to certify the continued enforceability of the decision by the fastest appropriate means'. ${ }^{51}$ And, as an incentive, where the enforcement of removal decisions generates costs, the Directive foresees that MSs compensate each other for any 'financial imbalances' that may result from their cooperation. ${ }^{52}$

With this objective of swiftness and efficiency in mind, the overall purpose of the Directive is to enable the trans-national recognition of an expulsion decision adopted by an 'issuing' MS against a TCN found in the territory of a different 'enforcing' MS on the basis of a SIS alert. ${ }^{53}$ Although the adoption of the expulsion decision follows the applicable rules of the issuing MS, any subsequent enforcement decisions 'shall be implemented according to the applicable legislation of the enforcing $\mathrm{MS}^{, 54}$ - so, while the traditional exequatur procedure is done away with, there is no full embracement of the 'home country' rule paradigm with regard to the execution part of the operation, which is somewhat 're-nationalised' by reference to the domestic laws (and independent EU obligations) of the enforcing MS, which will adopt its own, separate (sovereign) decision.

Per se, there are no grounds available to the enforcing MS, authorising the refusal of the execution of an expulsion decision adopted by the issuing MSalthough the general renvoi to 'the applicable legislation of the enforcing MS' obviates the need for a list of such grounds, since national discretion remains intact. By contrast, where the expulsion decision is motivated by security reasons, based either on a firm conviction for a crime punishable by incarceration of at least one year duration, ${ }^{55}$ or when there are, otherwise, 'serious grounds for believing' that the TCN concerned 'has committed a serious criminal offence', or where there is 'solid

\footnotetext{
${ }^{47}$ Schengen Information System II Regulation (EC) No 1987/2006, [2006] OJ L 381/4 ('SIS II').

${ }^{48}$ Arts 2(6) and 11, Return Directive. For analysis, see de Morree, 'Mutual Trust in Migration Law: The Returns Directive and Mutual Recognition of Entry Bans', in Battjes et al., The Principle of Mutual Trust in European Asylum, Migration and Criminal Law (Meijers Committee, 2011) 28.

${ }^{49}$ Recital 14, Preamble, Return Directive.

${ }^{50}$ Recital 3, Preamble, EDD (emphasis added).

${ }^{51}$ Art. 6 EDD (emphasis added).

${ }^{52}$ Art. 7 EDD.

${ }^{53}$ Art. 1(1) EDD. See also, Return Directive, Preamble, Recital 18.

${ }^{54}$ Art. 1(2) EDD (emphasis added).

${ }^{55}$ Cf. Case C-456/14 Orrego Arias ECLI:EU:C:2015:550.
} 
To be published as: Moreno-Lax, 'Mutual (Dis-)Trust in EU Migration and Asylum Law: The Exceptionalisation of Fundamental Rights', in González Pascual and Iglesias Sánchez (eds), Fundamental Rights in the EU Area of Freedom, Security and Justice (CUP, 2020).

evidence of his intention' to commit such offences-whatever these terms may be taken to mean and regardless of their implications for the principle of legality and the presumption of innocence-prior to the execution of the removal, any residence permit the person may hold in any MS should first be cancelled. ${ }^{56}$

However, the liberty to grant (or maintain) a residence permit to a TCN subject to an expulsion decision issued by another MS is not completely eliminated. ${ }^{57}$ A mechanism of consultation between the MS issuing the expulsion order, the enforcing MS, and the MS that granted/intends to grant the permit, is provided for to this effect. ${ }^{58}$ What is required is that account be taken of the security interests of the $\mathrm{MS}(\mathrm{s})$ involved $^{59}$ - their possible objections having pan-EU relevance under the Schengen acquis, and their decision to issue an expulsion decision, accompanied by an entry ban, normally having to be accorded EU-wide, cross-national effects. Yet, failure to engage in the consultation process with diligence may lead to the MS that issued the alert to be placed under an obligation to withdraw it — and put it, instead, in the national list of SIS alerts, signalling security threats affecting only national interests without full extraterritorial implications. ${ }^{60}$ The TCN concerned may then rely on the result of the consultation - which is deemed to produce 'legal effects' - in the national courts of the MS issuing the alert to ensure its withdrawal. ${ }^{61}$

In fact, the rights of the individual cannot be disregarded by any of the MSs involved - at least, in principle. ${ }^{62}$ On the one hand, the issuing MS must ensure that expulsion decisions are adopted in accordance with the safeguards contained in the $\mathrm{ECHR}^{63}$ and the Refugee Convention (CSR), ${ }^{64}$ paying particular attention to the prohibition of torture and the right to family life ${ }^{65}$ - the EU Charter not being mentioned, due to the Directive predating it, but, nevertheless, having to be taken into account post Lisbon. On the other hand, the enforcing MS, although not allowed to assess whether the issuing MS has indeed complied with its obligations, is subject by a separate duty to provide remedies under its national law against any enforcement measure it may independently adopt to implement the expulsion decision. ${ }^{66}$

So, in the end, it appears that, rather than there being a (real) mechanism of mutual recognition, the system introduces a de-coupling of the (original) expulsion decision adopted by one MS (the validity of which is never contested, nor contestable, and which the other MSs must acknowledge and act upon), from the (subsequent) decision to execute it adopted by another MS - which, for the purposes of the person concerned, virtually becomes a new, fresh decision to remove her from the EU under

\footnotetext{
${ }^{56}$ Art. 3(1)(a), final indent, EDD.

${ }^{57}$ Cf. Art. 6(2), Return Directive.

${ }^{58}$ This is provided for in Art. 25 CISA, which is still in force.

${ }^{59}$ Art. 11(4), Return Directive.

${ }^{60}$ Case C-240/17 E ECLI:EU:C:2018:8, Ruling, para. 2.

${ }^{61}$ Ibid., Ruling, para. 3 . What is not clear is what happens in case of a conflict between the MSs.

${ }^{62}$ Art. 3(2) EDD.

${ }^{63}$ European Convention on Human Rights, [1950] E.T.S. 5 ('ECHR').

${ }^{64}$ Convention Relating to the Status of Refugees, [1951] 189 U.N.T.S. 150 ('CSR').

${ }^{65}$ Recital 4, Preamble, EDD.

${ }^{66}$ Art. 4 EDD. See also Arts 13-18, Return Directive, on remedies and pre-removal detention.
} 
To be published as: Moreno-Lax, 'Mutual (Dis-)Trust in EU Migration and Asylum Law: The Exceptionalisation of Fundamental Rights', in González Pascual and Iglesias Sánchez (eds), Fundamental Rights in the EU Area of Freedom, Security and Justice (CUP, 2020).

the domestic law of the expelling MS (and the harmonised rules of the Return Directive). Therefore, rather than a single decision 'traveling' from one jurisdiction to the next and enabling the enforcement capacity of the issuing MS via the executing $\mathrm{MS},{ }^{67}$ there is, instead, a 'succession' of separate decisions which complement one another on the basis of a SIS alert issued by either one of them or any other MS, which is taken at face value and automatically 'internalised' by all Schengen countries. What is mutualised and immediately recognised is the SIS alert, rather than any specific, pre-existing decision to expel-the antiquity of the alert, its proportionality, and any other circumstances surrounding it not being specifically addressed by the EDD regime. This is probably why the Directive is rarely relied upon and has produced virtually no case law. ${ }^{68}$

Ultimately, what counts is the SIS hit detected by any country connected to the system; it is the SIS that sets the trans-national removal trail in motion and creates a mechanism of automatic 'collectivised recognition' based on (virtually absolute) trust. To counterbalance any 'excess trust', the SIS Regulation foresees that the competent authorities in any of the SIS members are bound by the obligation to allow the 'data subject' concerned to 'access, correct, delete or obtain information in connection with an alert relating to him'. ${ }^{69}$ SIS members undertake, then, 'mutually to enforce [any ensuing] final decision ${ }^{, 70}$ - without any rules, criteria or procedure, however, being indicated to this effect.

The control on trust in this framework is thus re-allocated to the individual, who remains, in principle, free to submit any fundamental rights issues against the issuing MS and/or the executing MS that the enforcement of the expulsion measure(s) may give rise to (in each jurisdiction). There is, thereby, a transfer from the horizontal level - at which ex ante unconditional (or "blind ${ }^{71}$ ) trust is manifested between MSs detecting a SIS hit — to the vertical level — at which trust is withheld ex post and may be resisted by the individual affected. In principle, the possibility to challenge the ensuing expulsion is without any explicit limitations regarding the invocable rightswith the caveat that not all SIS members are also bound by the harmonised Return Directive guarantees. ${ }^{72}$ This is important because, as the next section shows, by contrast, within the Dublin system, forcible transfers of asylum claimants between MSs are subject to more stringent criteria to resist (intra-EU) removals and can do so on selected (and very exceptional) grounds only.

\footnotetext{
${ }^{67}$ As the case typically is within, e.g., the EAW scheme. For a critique, see Konstadinides, 'The Perils of the "Europeanisation" of Extradition Procedures in the EU: Mutuality, Fundamental Rights and Constitutional Guarantees' (2007) 14 MJ 179.

${ }^{68}$ For a similar conclusion, see ECRE, Mutual Recognition of Positive Asylum Decisions and the Transfer of International Protection Status within the EU (November 2014), at 10-11.

${ }^{69}$ Art. 43(1) SIS II.

${ }^{70}$ Art. 43(2) SIS II (emphasis added). On related problems, see Brouwer, Digital Borders and Real Rights (Brill, 2008), specially at 526-527.

${ }^{71}$ Lenaerts, 'La Vie après 1'Avis: Exploring the Principle of Mutual (Yet Not Blind) Trust' (2017) 54 CMLRev 805.

${ }^{72}$ This includes, e.g., the UK and Ireland. See Recitals 26 and 27, Preamble, Return Directive.
} 
To be published as: Moreno-Lax, 'Mutual (Dis-)Trust in EU Migration and Asylum Law: The Exceptionalisation of Fundamental Rights', in González Pascual and Iglesias Sánchez (eds), Fundamental Rights in the EU Area of Freedom, Security and Justice (CUP, 2020).

\section{Mutual Recognition and EU Asylum Law}

The exclusion from free movement rights and the securitisation of their movement also affects applicants of international protection. Since protection should benefit only genuine refugees, who 'legitimately' seek it, ${ }^{73}$ mechanisms have emerged to set them apart. The notion of 'asylum-seeker' or 'asylum applicant' plays a key role in this regard. ${ }^{74}$ Despite formal acceptance in EU law that status determination is a declaratory act and that a person is a refugee as soon as she meets the Refugee Convention definition, ${ }^{75}$ the term has been used, in practice, to withhold related rights, which are only fully extended after completion of the determination procedure. ${ }^{76}$ Most importantly, this approach has led to the assimilation of asylum seekers to the general category of TCNs for migration management purposes, so that, prior to having lodged an application (in EU territory), rather than being considered as putative refugees - unless in possession of the requisite documentation - they are treated as 'illegal migrants'. And, because there are no visas to enter the Schengen zone to request asylum upon arrival, ${ }^{77}$ up to $90 \%$ of those who eventually become recognised refugees enter the EU clandestinely. ${ }^{78}$ The end result is the securitisation of asylum flows, ${ }^{79}$ which makes the intended recipients of international protection also the object of the 'fight against illegal immigration'.

One significant consequence of the securitisation of asylum flows is the general distrust of potentially 'bogus' claimants that pervades the CEAS, ${ }^{80}$ which has had an impact on how mutual recognition tools have been designed and employed on the ground. As the next sub-sections illuminate, the overall tendency towards deterrence and restriction seen in EU migration policy is equally visible in EU asylum law. ${ }^{81}$ While the mutual recognition of rights-granting decisions between MSs is under-developed, the mutual recognition of rights-restricting decisions has been given EU-wide endorsement and near-automatic effects.

\subsection{Mutual Recognition of Rights-conferring Measures}

\footnotetext{
${ }^{73}$ See common Recital 2, Preamble, Qualification Directive 2011/95/EU, [2011] OJ L 337/9 ('QD'); Reception Conditions Directive 2013/33/EU, [2013] OJ L 180/96 ('RCD'); Asylum Procedures Directive 2013/32/EU, [2013] OJ L 180/60 ('APD'); and DRIII (emphasis added).

${ }^{74}$ Art. 1 CISA; common Art. 2(c) DRIII and APD; and Art. 2(b) RCD.

${ }^{75}$ Recital 21, Preamble, QD.

${ }^{76}$ Warning against this approach, see Hathaway, 'What's In a Label?' (2003) 5 EJML 1.

${ }^{77}$ For a detailed critique, see Moreno-Lax, 'The Added Value of EU Legislation on Humanitarian Visa: Legal Aspects', Annex I, European Added Value Assessment accompanying the European Parliament's legislative own-initiative report (Rapp. Lopez Aguilar) on Humanitarian Visas (Brussels: European Parliament, 2018).

${ }^{78}$ European Parliament resolution of 11 December 2018 with recommendations to the Commission on Humanitarian Visas (2018/2271(INL)), Recital E.

${ }^{79} C f$. Mitsilegas, Moreno-Lax and Vavoula (eds.), Securitising Asylum Flows (Brill, 2020).

${ }^{80}$ See further Moreno-Lax, 'Life after Lisbon: EU Asylum Policy as a Factor of Migration Control', in Acosta and Murphy (eds.), EU Justice and Security Law (Hart, 2014) 146.

${ }^{81}$ See, e.g., Den Heijer, Rijpma and Spijkerboer, 'Coercion, Prohibition, and Great Expectations: The Continuing Failure of the Common European Asylum System’ (2016) 53 CMLRev 607.
} 
To be published as: Moreno-Lax, 'Mutual (Dis-)Trust in EU Migration and Asylum Law: The Exceptionalisation of Fundamental Rights', in González Pascual and Iglesias Sánchez (eds), Fundamental Rights in the EU Area of Freedom, Security and Justice (CUP, 2020).

The mutual recognition of positive asylum decisions has been considered a possible intermediary step ${ }^{82}$ towards the full realisation of the objective of establishing ' $a$ common asylum procedure and a uniform status for those who are granted asylum valid throughout the Union' ${ }^{83}$ And this EU-wide validity has been interpreted as having to entail the possibility to transfer acquired rights, after status recognition, between different MSs. ${ }^{84}$ But, so far, little progress has been made.

Instead, what one witnesses is a very partial recognition of extraterritorial effects of positive asylum decisions adopted by one MS in relation to other CEAS partners. For example, under the current Visa Regulation, 'refugees... who reside in a MS and are holders of a travel document issued by that MS...shall...be exempt from the visa requirement' and be granted visa-free travel for up to three months ${ }^{85}$ - just like non-refugee Schengen visa grantees are normally allowed to. ${ }^{86}$ This, in fact, involves an implicit recognition by the other MSs of the validity of the decision adopted by one of them recognising the refugee status of the person concerned and attaching short-term mobility rights to that recognition.

However, this mechanism arguably does no more than honouring obligations directly stemming from the Refugee Convention - to which all MSs and Schengen partners have adhered and in conformity with which the CEAS must be established. ${ }^{87}$ Indeed, under the Refugee Convention, contracting States are under a legal obligation to issue Convention Travel Documents to refugees and to recognise those issued by other fellow contracting States for the purpose of admitting the refugees concerned. ${ }^{88}$ This, therefore, implies the mutual recognition of the validity of refugee status recognition decisions by all parties. ${ }^{89}$ Nonetheless, the scheme does not go so far as to making explicit whether a full transfer of responsibility for the protection obligations attached to refugee status occurs as a result. ${ }^{90}$ The Schedule attached to the Convention establishes only that, once a recognised refugee settles in a different contracting party, responsibility to issue any new Travel Document is transferred to the new State of residence. ${ }^{91}$ But it does not stipulate the conditions under which that

\footnotetext{
${ }^{82}$ See, e.g., Action Plan Implementing the Stockholm Programme, COM(2010) 171 final, p. 55.

${ }^{83}$ Tampere Conclusions, 15-16 October 1999, para. 15 (emphasis added); and Art. 78(2)(a)-(b) TFEU.

${ }^{84}$ Stockholm Programme, [2010] OJ C 115/1, para. 6.2.1.

${ }^{85}$ Art. 1(1)-(2), Visa Regulation 539/2001, [2001] OJ L 81/1, as amended by Regulation 1932/2006, [2006] OJ L 405/23.

${ }^{86}$ This arrangement reproduces the content of the European Agreement on the Abolition of Visas for Refugees, [1959] E.T.S. 31.

${ }^{87}$ Art. 78(1) TFEU and Art. 18 CFR.

${ }^{88}$ Art. 28 CSR and related Schedule, para. 7. See also Vested-Hansen, 'Article 28 and Schedule', in Zimmermann (ed.), The 1951 Convention Relating to the Status of Refugees (OUP, 2011) ch 56.

${ }^{89}$ See also EXCOM Conclusion No 12 (XXIX) 1978 on Extraterritorial Effect of the Determination of Refugee Status <https://www.unhcr.org/uk/excom/exconc/3ae68c4447/extraterritorial-effectdetermination-refugee-status.html $>$.

${ }^{90}$ In fact, contracting parties have not interpreted these provisions to entail such a transfer. See Peers, 'Transfer of International Protection and European Union Law' (2012) 24 IJRL 527.

${ }^{91}$ Schedule, para. 11. UNHCR has noted, in this regard, that no new status determination procedure should take place at this point. See Note on the Extraterritorial Effect of the Determination of Refugee Status under the 1951 Convention, 24 August 1978, UN doc. EC/SCP/9, para. 32.
} 
To be published as: Moreno-Lax, 'Mutual (Dis-)Trust in EU Migration and Asylum Law: The Exceptionalisation of Fundamental Rights', in González Pascual and Iglesias Sánchez (eds), Fundamental Rights in the EU Area of Freedom, Security and Justice (CUP, 2020).

new settlement can take place and whether - and, if so, at which point and to which extent - any other responsibilities are also transferred.

A Council of Europe Agreement on Transfer of Responsibility for Refugees, ${ }^{92}$ ratified by 11 EU MSs, goes some way into clarifying these matters. Although the agreement does not award refugees a right to move between the territories of the Contracting Parties, it regulates some aspects of their situation in the event they are authorised to take up residence in a State party different from the one that recognised their status. Accordingly, under Article 2 of the Agreement, responsibility to cater for the rights attached to refugee status is supposed to be transferred two years (of continuous and actual stay) after admission in the second State party. At that point, the second State party is required to honour (presumably all) the 'rights and advantages flowing from the Geneva Convention'. ${ }^{93}$

No such scheme has been provided for under EU law. The current rules determine that the MS responsible to examine an asylum application, once granted, is also responsible to deliver the protection rights attached to refugee status or subsidiary protection (SP) status. International protection beneficiaries are not free to move and take up residence in a different MS, unless they obtain LTR status under (the separate regime of) the LTR Directive. ${ }^{94}$ But the two statuses cannot be accumulated, so upon receipt of LTR status, the person concerned would move qua LTR permit holder, rather than qua refugee or SP beneficiary, the rights attached to international protection not being transferable between MSs. ${ }^{95}$ What is more, if the person concerned were to lodge a new asylum application in the second MS, that second MS would be entitled to treat the claim as inadmissible and reject it without any assessment of the merits. ${ }^{96}$ This way, under the CEAS, a positive decision on an asylum application by the first MS is accorded some form of recognition by the second MS, but only as a basis to reject without review a subsequent claim. Instead of as a vehicle to extend the claimant's rights - so they produce (extraterritorial) effects in the second MS - the existence of a positive decision by a first MS is relied upon to negate any responsibility by the second MS to honour the rights concerned. ${ }^{97}$ The (implicit) mutual recognition scheme at play here is, therefore, used to curtail, rather than expand, the (EU) rights of international protection beneficiaries, denying them EU-wide cross-national strength.

\subsection{Mutual Recognition of Rights-restricting Measures}

\footnotetext{
${ }^{92}$ European Agreement on Transfer of Responsibility for Refugees, [1980] E.T.S. 107.

${ }^{93}$ Parliamentary Assembly of the Council of Europe, Explanatory Report, PACE doc. 3703, para. 31.

${ }^{94}$ See further, Boelaert-Suominen, 'Non-EU nationals and Council Directive 2003/109/EC on the status of third country nationals who are long-term residents' (2005) 42 CMLRev 1011.

${ }^{95}$ Cf. Lassen et al., The Transfer of Protection Status in the EU, Final Report, D.JAI/A2/2003/001 (European Commission, 2004).

${ }^{96}$ Art. 33(2)(a) APD.

${ }^{97}$ Guild et al., Enhancing the Common European Asylum System and Alternatives to Dublin, PE 519.234 (European Parliament, 2015), p. 43.
} 
To be published as: Moreno-Lax, 'Mutual (Dis-)Trust in EU Migration and Asylum Law: The Exceptionalisation of Fundamental Rights', in González Pascual and Iglesias Sánchez (eds), Fundamental Rights in the EU Area of Freedom, Security and Justice (CUP, 2020).

It is the (implicit) mutual recognition of negative asylum decisions that is predominant within the CEAS. If a person's application has been rejected by a first MS, any subsequent application in any other MS can be considered inadmissible and unfounded. ${ }^{98}$ On the basis of that negative decision, the second MS can decline to examine the substance of the application and, in so doing, it effectively recognises (without any specific formalities, procedures, or guarantees) the legal validity of the (negative) decision adopted by the first MS. On those grounds, according to Dublin transfer rules, the first MS is under a duty to 'take back' the person concerned - and proceed to her expulsion under the Return Directive. ${ }^{99}$

Indeed, the Dublin system for responsibility allocation for the examination of international protection claims among participating MSs and Schengen partners is based on the assumption that 'all [these countries] respecting the principle of nonrefoulement, are considered as safe...for TCNs', so that transfers of asylum applicants inter se, through the 'take back' or the 'take charge' procedures, ${ }^{100}$ are presumed to respect 'the full and inclusive application of the Geneva Convention'. ${ }^{101}$ The N.S. ruling takes this presumption as the basis for the principle of mutual trust (rather than mutual recognition as such). ${ }^{102}$ According to the CJEU, '[i]t is precisely because of that principle...that the EU legislature adopted [the Dublin] Regulation', pursuing the 'principal objective of...speed[ing] up the handling of claims' ${ }^{103}$ This is supposed to be for the benefit not only of participating States, but also of the asylum seekers themselves, considering the increase in legal certainty that a clear system of allocation of responsibility is deemed to entail. ${ }^{104}$

In principle, trust under these arrangements 'must be assumed', on the grounds that - regardless of practical realities and vast differences in recognition rates across the $\mathrm{EU}^{105}$ - 'the treatment of asylum seekers in all MSs complies with...the Charter, the Geneva Convention and the ECHR'. ${ }^{106}$ It is only where an applicant adduces that there are 'substantial grounds for believing that there are systemic flaws in the asylum procedure and reception conditions for asylum applicants in the MS responsible, resulting in inhuman or degrading treatment, within the meaning of Article 4 of the Charter...[that] the transfer would be incompatible with that provision'. ${ }^{107}$ Other 'minor infringements' - however these may be defined - are not considered serious enough to quash the presumption, and are taken to amount to an unjustified

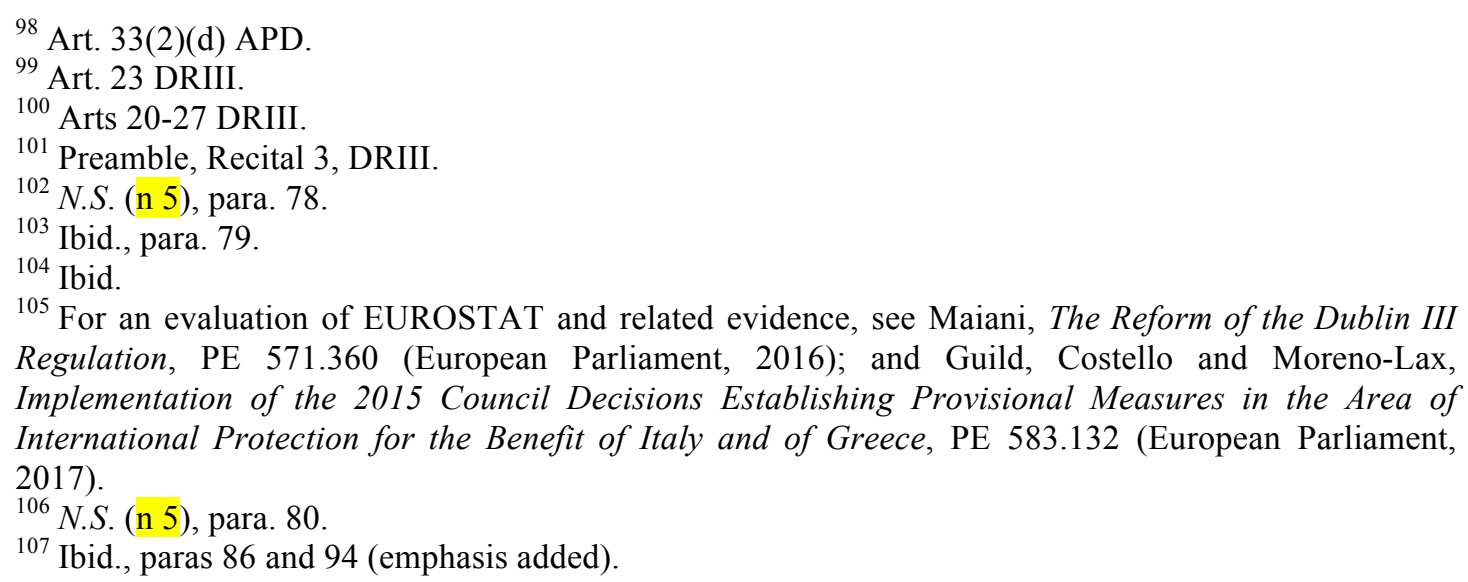


To be published as: Moreno-Lax, 'Mutual (Dis-)Trust in EU Migration and Asylum Law: The Exceptionalisation of Fundamental Rights', in González Pascual and Iglesias Sánchez (eds), Fundamental Rights in the EU Area of Freedom, Security and Justice (CUP, 2020).

exoneration from Dublin obligations. ${ }^{108}$ So, while the presumption of compliance with fundamental rights, justifying mutual trust, is rebuttable, ${ }^{109}$ it is only in the most extreme of situations that it can be overturned. And the consequence of rebutting the presumption is not the halting of the related Dublin transfer. Rather, 'the MS which should carry out that transfer must continue to examine the [responsibility] criteria...to establish whether one of the [other criteria listed] enables another MS to be identified as responsible'. ${ }^{110}$ It is only if such an alternative country cannot be identified within a 'reasonable time' that the MS where the applicant is present must assume responsibility. ${ }^{111}$

The requirement of systemic flaws as the sole relevant source of Article 4 CFR risks was vehemently defended in Abdullahi as 'the only way' in which an asylum applicant could challenge a Dublin transfer. ${ }^{112}$ The judgment also appeared to make it the onus of the applicant to herself 'plead' the existence of such systemic deficiencies - rather than it being for the authorities concerned to establish them ex officio on the basis of public information 'they cannot be unaware [of]'. ${ }^{113}$ Speed and effectiveness in the handling of claims were, again, mentioned as the 'principal objective' of this scheme, ${ }^{114}$ emphasising 'the relations between the MSs', rather than the fulfilment of fundamental rights, as the motivating factor. ${ }^{115}$

It has only been after the 2013 reform that the rights of claimants have gained some prominence. Ghezelbash made clear that the right to an effective remedy in Article 27 of the recast Regulation includes the possibility for claimants to contest the incorrect application of the responsibility criteria to resist transfer-whether there are systemic flaws and an Article 4 CFR risk ensues or not. ${ }^{116}$ The rationale, for the Court, is the wish of the EU legislature - rather than the legally-binding force of the Charter-to 'enhance' the rights of asylum applicants, 'guaranteeing [their] involvement in the process for determining the MS responsible'. ${ }^{117}$ Instead of 'simply governing relations between MSs for the purpose of determining the MS responsible', the recast Regulation is considered intended to 'involve asylum seekers in that process'. ${ }^{118}$ This is why '[a] restrictive interpretation of the scope of the remedy provided in Article 27 [DRIII] might...thwart the attainment of that objective'. ${ }^{119}$

\footnotetext{
${ }^{108}$ Ibid., paras 85 and 83 .

${ }^{109}$ Ibid., paras 99 and 104.

${ }^{110}$ Ibid., para. 96.

111 Ibid., paras 97 and 98.

${ }^{112}$ Case C-394/12 Abdullahi ECLI:EU:C:2013:813, paras 60 and 62 (emphasis added). Confirming: Case C-4/11 Puid ECLI:EU:C:2013:740.

${ }^{113}$ N.S. (n 5), para. 94, in line with ECtHR, M.S.S. v Belgium and Greece, Appl. 30696/09, 21 January 2011. Cf. Moreno-Lax, 'Dismantling the Dublin System: M.S.S. v Belgium and Greece' (2012) 14 EJML 1.

${ }^{114}$ Abdullahi (n 112), paras 53 and 59.

${ }^{115}$ Ibid., para. 56.

${ }^{116}$ Case C-63/15 Ghezelbash ECLI:EU:C:2016:409, para. 37. Confirming: Case C-155/15 Karim ECLI:EU:C:2016:410.

${ }^{117}$ Ghezelbash (n 116), para. 46.

${ }^{118}$ Ibid., para. 51.

${ }^{119}$ Ibid., para. 53.
} 
To be published as: Moreno-Lax, 'Mutual (Dis-)Trust in EU Migration and Asylum Law: The Exceptionalisation of Fundamental Rights', in González Pascual and Iglesias Sánchez (eds), Fundamental Rights in the EU Area of Freedom, Security and Justice (CUP, 2020).

Although this triangulation between the relations of the MSs inter se with the asylum applicants subject to Dublin transfers virtually changes the configuration of mutual confidence by adding new players to the equation, this has, however, been considered to have 'no bearing on the principle of mutual trust' as previously understood. ${ }^{120}$ For the Court, if in the course of the process of allocating responsibility an error has been made, 'such a finding would simply mean that the MS to which the applicant was to be transferred was not the MS responsible within the meaning of the criteria $^{121}$ - since the mutual confidence embedded in Dublin provisions relates to the correct application of the relevant rules. ${ }^{122}$ The fact that the correct application of the relevant rules, as the system has been designed, is to be guaranteed ex post by the asylum applicant resisting her transfer in the individual case, rather than ex ante by the MSs concerned checking compliance with the rules in good faith, is not taken by the Court as a sign of structural failing in the configuration of the regime.

Dublin, with its intrinsically punitive approach towards the allocation of responsibility for asylum claims, creates perverse incentives. The 'authorisation principle' underpinning the so-called 'country of first entry' rule, if correctly applied, would entail a concentration of responsibility in the MSs placed at the external borders of the EU - an outcome hardly compatible with the principle of solidarity and fair sharing of responsibility introduced in Article 80 TFEU. Jafari makes this clear. The Dublin system is ancillary to the working of the Schengen cooperation, and it is therefore premised upon the idea that 'each MS is answerable to all the other MSs for its actions concerning the entry and residence of TCNs' (including refugees). ${ }^{123}$ This is why, if they fail in sufficiently controlling (their section of) the EU external border, they 'must bear the consequences thereof'. ${ }^{124}$ Through this lens, Dublin, as a whole, is a system of 'organised distrust' that emerges as a palliative, to remedy ex post the border surveillance deficiencies of frontline countries that fail to prevent the irregular entry of unwanted migrants. Both the system rules and the Court itself omit, however, that those same countries are under an obligation not to refuse entry because of their EU and international law commitments, in particular the principle of non-refoulement. The Court goes even further in Jafari and establishes that 'entry authorised in that context' (which it, however, links to 'humanitarian grounds' rather than to any legal obligations) 'cannot be regarded as an entry [in line with Schengen rules]', ${ }^{125}$ it rather remains an irregular entry, 'irrespective of whether [it] was tolerated or [expressly] authorised'. ${ }^{126}$ The opposite, according to the Court, would amount to absolving the MS concerned of its Schengen duties and, therefore, 'be inconsistent with the general

\footnotetext{
${ }^{120}$ Ibid., para. 55.

${ }^{121}$ Ibid.

122 See also Case C-670/16 Mengesteab ECLI:EU:C:2017:587; Case C-201/16 Shiri ECLI:EU:C:2017:805; Case C-360/16 Hasan ECLI:EU:C:2018:35; and Case C-647/16 Hassan ECLI:EU:C:2018:368.

${ }^{123}$ Case C-646/16 Jafari ECLI:EU:C:2017:586, para. 88.

${ }^{124}$ Ibid.

${ }^{125}$ Ibid., para. 82.

${ }^{126}$ Ibid., para. 92.
} 
To be published as: Moreno-Lax, 'Mutual (Dis-)Trust in EU Migration and Asylum Law: The Exceptionalisation of Fundamental Rights', in González Pascual and Iglesias Sánchez (eds), Fundamental Rights in the EU Area of Freedom, Security and Justice (CUP, 2020).

scheme and objectives of the Dublin III Regulation'-again, ignoring the higher rank, as primary EU law and customary international law, if not a jus cogens norm, of the principle of non-refoulement. ${ }^{127}$

This punitive understanding of Dublin transfers, as punishment for noncompliance with border control obligations (disconnected from the principle of nonrefoulement), is at the core of the Dublin rules. Priority is given to the preservation of the Schengen objective of exclusionary realisation of the AFSJ that ' $[\mathrm{t}]$ he Union shall offer its citizens' ${ }^{128}$ This is why, although Ghezelbash opened up new avenues for resisting transfer beyond the 'systemic flaws' scenario, subsequent case law has made clear that only very 'exceptional situations'-outside the incorrect application of the Dublin criteria - protect against forcible removal. ${ }^{129}$

It is only potential breaches of Article 4 CFR that reach the threshold. C.K., given its absolute character and its connection to human dignity, ${ }^{130}$ abandons the link to 'systemic deficiencies', ${ }^{131}$ and concludes that a transfer 'in itself' may result, in individual cases, 'in a real risk of inhuman or degrading treatment...irrespective of the quality of the reception and the care available in the MS responsible for examining [the] application'. ${ }^{132}$ If there is a 'real and proven risk of a significant and permanent deterioration... of [the applicant's] health' the transfer must be considered incompatible with Article 4 CFR. ${ }^{133}$ The initial burden of proof rests with the applicant, though, to provide 'objective evidence' demonstrating 'the particular seriousness of his state of health and the significant and irreversible consequences to which his transfer might lead'. ${ }^{134}$ The competent authorities cannot then 'ignore that evidence'; they must, on the contrary, assess it and eventually 'eliminate any serious doubts concerning the impact of the transfer'. ${ }^{135}$ But this alone does not prevent the transfer. If the transferring MS, in cooperation with the MS responsible, can adopt sufficient precautions and 'ensure that the asylum seeker concerned receives health care during and after the transfer', the removal can take place. ${ }^{136}$ Even when precautions are insufficient, the transfer is not cancelled outright, only 'suspended' for as long as '[the applicant's] state of health renders him unfit for such a transfer'. Only if the transfer cannot proceed within the six-month period for 'take back' procedures, will it be halted and responsibility transferred to the transferring MS. ${ }^{137}$

\footnotetext{
${ }^{127}$ Ibid., paras 83, 84 and 89. Cf. Costello and Foster, 'Non-refoulement as Custom and Jus Cogens? Putting the Prohibition to the Test' (2015) 46 NYIL 273.

${ }^{128}$ Art. 3(2) TEU (emphasis added).

${ }^{129}$ Case C-578/16 PPU C.K. ECLI:EU:C:2017:127, para. 95.

${ }^{130}$ Ibid., paras 59 and $91-93$.

${ }^{131}$ See also Case C-163/17 Jawo ECLI:EU:C:2019:218, para 87.

${ }^{132}$ C.K. (n 129), para. 73.

${ }^{133}$ Ibid., para. 74 (emphasis added). This demand for a 'proven risk' arguably raises the bar above what Art. 3 ECHR normally requires, destabilising the equivalence of 'meaning and scope' between Art. 4 CFR and Art. 3 ECHR, required by Art. 52(3) CFR.

${ }^{134}$ Ibid., para. 75.

${ }^{135}$ Ibid., para. 76.

${ }^{136}$ Ibid., paras 77-80.

${ }^{137}$ Ibid., para. 89.
} 
To be published as: Moreno-Lax, 'Mutual (Dis-)Trust in EU Migration and Asylum Law: The Exceptionalisation of Fundamental Rights', in González Pascual and Iglesias Sánchez (eds), Fundamental Rights in the EU Area of Freedom, Security and Justice (CUP, 2020).

This 'exceptionalisation' of fundamental rights protections - treating them as exceptions to mutual trust rather than as their baseline, referent rule, and ultimate aspiration ${ }^{138}$ - has been corroborated in Jawo $^{139}$ — and it tallies with the general approach to mutual trust embraced in Opinion 2/13. The judgment in that case reiterated the importance of Article 4 CFR as an absolute provision, stating that the CEAS and the principle of mutual trust itself 'depend on the guarantee that the application of that system will not result, at any stage and in any form in a serious risk of infringements of Article 4 of the Charter'. ${ }^{140}$ However, it concluded that only very grave violations would count; the threshold of inhuman or degrading treatment being reached only in extreme circumstances, excluding 'situations characterised even by a high degree of insecurity or a significant degradation of the living conditions of the person concerned, where they do not entail extreme material poverty'. ${ }^{141}$ With this, not only other fundamental rights in the Charter, but also those specifically harmonised at EU level in the CEAS instruments are sidelined. Indeed, in this way, the 'standard of protection of fundamental rights guaranteed by EU law', ${ }^{142}$ for Dublin transferees, becomes reduced to (a very restrictive reading of) Article 4 CFR alone. Mutual trust, as interpreted within the Dublin scheme, thus amounts to a divestiture of the rights enshrined in the asylum acquis, the Refugee Convention, and the ECHR - which, paradoxically, are supposed to be the instruments justifying the presumption of compliance in the first place. ${ }^{143}$ In this framework, (formal) mutual trust not only does not expand rights protection across MSs, affirming their EU-wide reach, but it substantiates their (material) reduction to the bare minimum, discounting harmonised standards the violation of which is considered of lesser importance than the integrity of the Schengen regime.

\section{Conclusions: The 'Exceptionalisation' of Fundamental Rights}

Overall, what this chapter demonstrates is a mismatch between formally proclaimed mutual trust and real-world distrust in the EU migration and asylum policy realm. It has been exposed how horizontal trust between MSs is predominantly shown with regard to restrictive measures that agglutinate national 'prohibitions and restrictions', ${ }^{144}$ adding up domestic security-based concerns and elevating them to the transnational sphere, curtailing TCN rights by accumulation. Thereafter, forcible transfers, expulsion orders, entry bans, and especially SIS alerts are accorded (implicit) 'collectivised' recognition in practically automatic fashion, without any

\footnotetext{
${ }^{138} \mathrm{Cf}$. Arts 2 and 6 TEU and Art. 51 CFR.

${ }^{139}$ Jawo (n 131).

${ }^{140}$ Ibid., para. 89 (emphasis added).

${ }^{141}$ Ibid., para. 93 (emphasis added). This seems to conflate torture, inhuman treatment, and degrading treatment, recognising as relevant only the upper tier of ill-treatment and dismissing that Art. 4 CFR also protects against the other two lesser forms of abuse.

142 Ibid.

${ }^{143}$ Ibid., para. 82.

${ }^{144}$ Art. 17, Schengen Agreement.
} 
To be published as: Moreno-Lax, 'Mutual (Dis-)Trust in EU Migration and Asylum Law: The Exceptionalisation of Fundamental Rights', in González Pascual and Iglesias Sánchez (eds), Fundamental Rights in the EU Area of Freedom, Security and Justice (CUP, 2020).

possibility for the enforcing MS to check and contest the validity of the measure concerned - it rather being expected to rely on both the issuing country's and its own security-based preoccupations to exclude and expel the TCN in question. By contrast, vertical trust, towards the TCN affected by the measure, is virtually non-existent-her presence having been securitised as a potential threat to all countries implicated and the EU as a whole, particularly with a view to preserving the Single Market and the Schengen cooperation. The mobility of non-citizens in this context is, thus, conceived of as a reward for law-abidance and societal integration, rather than as a legal entitlement based on fundamental rights.

What, however, sets the mechanism of mutual recognition of restrictive immigration and asylum decisions apart from similar schemes within the AFSJ is the explicit provision that has been made herein for an ex post 'control on trust', which is transferred from the horizontal to the vertical level to ensure at least minimum compliance with fundamental guarantees via specific remedies that may make good any excess of (unwarranted) confidence between the MSs. Yet, while the spectrum of rights that may be invoked to resist coercion in relation to restrictive immigration decisions is not specifically limited, within the Dublin regime it is only the most egregious violations that can halt a transfer - trust otherwise being irrefutable.

The final effect is an 'exceptionalised' and impoverished EU standard of fundamental rights protection of Dublin transferees, which is virtually reduced to Article 4 CFR only. Whether this is the intended effect of the joint adherence by all MSs to 'a set of common values on which the EU is founded' remains contested. ${ }^{145}$ The reduction of fundamental rights protection in practice that this entails negates the real-world effectiveness of EU law. By allowing utter variations in implementation across jurisdictions, behind an abstract presumption of equivalence that disregards the importance of (what are discarded as) 'minor infringements' of asylum obligations, ${ }^{146}$ the Dublin regime - as construed by the CJEU-openly tolerates the real inequivalence of the level of protection offered by the MSs on the ground. This interpretation, 'inasmuch as it would allow a MS to [de facto] disapply EU legal rules', ultimately brings into question the supremacy and uniform application of EU law, ${ }^{147}$ hence contesting the most 'essential characteristics' of the 'constitutional structure of the EU'. 148

By contrast, as the Court itself stated in Melloni, 'the principle of primacy of EU law...[requires that] rules of national law [as well as their implementation]...cannot be allowed to undermine the effectiveness of EU law on the territory of [any Member] State'. ${ }^{149}$ '[N] ational authorities and courts remain free to apply national standards of protection of fundamental rights, provided that the level of

\footnotetext{
${ }^{145}$ Jawo (n 131) para. 80.

${ }^{146}$ N.S. (n 5) para. 85.

${ }^{147}$ Case C-399/11 Melloni, ECLI:EU:C:2013:107 para. 58.

148 Opinion 2/13 (n 3), paras 165-167.

${ }^{149}$ Melloni (n 147), para. 59.
} 
To be published as: Moreno-Lax, 'Mutual (Dis-)Trust in EU Migration and Asylum Law: The Exceptionalisation of Fundamental Rights', in González Pascual and Iglesias Sánchez (eds), Fundamental Rights in the EU Area of Freedom, Security and Justice (CUP, 2020).

protection provided for by the Charter...[is] not thereby compromised'. ${ }^{150}$ And the level of protection provided for by the Charter is not just the protection against torture enshrined in Article 4 CFR. The minimum standard of protection under EU asylum (including Dublin) law is the one reflected in the asylum Directives, based on (all applicable) Charter rights, the ECHR and the Refugee Convention, ${ }^{151}$ which CEAS instruments are supposed to harmonise. Going below that harmonised standard within the Dublin regime amounts to a plain violation of the 'consensus reached by all the MSs regarding the scope to be given under EU law to the...rights [of asylum applicants]'. ${ }^{152}$ So, in the face of sub-standard national protection, contravening the Reception Conditions Directive and Qualification Directive provisions, abstract trust must give way to practical reality and take heed of legal obligations. The 'objectivation' of the principle of mutual confidence cannot be instrumentalised in a way such as to sustain and legitimise a dispossession of $E U$ fundamental rights.

\footnotetext{
${ }^{150}$ Ibid., para. 60.

${ }^{151}$ On the 'aggregate standards' approach to interpreting EU rights, see Moreno-Lax (n 44) ch 7.

${ }^{152}$ Melloni (n 147) para. 62.
} 